\author{
Asian Journal of \\ Medical and Biological Research \\ ISSN 2411-4472 (Print) 2412-5571 (Online) \\ www.ebupress.com/journal/ajmbr
}

\title{
Article \\ Dietary supplementation of wheatgrass powder to assess somatic response of
juvenile grass carp (Ctenopharyngodon idella)
}

\author{
K. M. Shakil Rana ${ }^{1 *}$, M. A. Salam ${ }^{1}$, Md. Rakib Ahmmed ${ }^{1}$ and Al Minan Noor ${ }^{2}$ \\ ${ }^{1}$ Department of Aquaculture, Bangladesh Agricultural University, Mymensingh, Bangladesh \\ ${ }^{2}$ Department of Fisheries, 13, Shohid CaptainMoonsur Ali Sharani, Matshya Bhaban, Ramna, Dhaka, \\ Bangladesh
}

*Corresponding author: K. M. Shakil Rana, Department of Aquaculture, Bangladesh Agricultural University, Mymensingh-2202. Phone: +8801728300299; E-mail: ranakms@ bau.edu.bd

Received: 19 August 2020/Accepted: 23 September 2020/ Published: 30 September 2020

\begin{abstract}
Consequence of dietary fish meal substitution with wheatgrass was evaluated by observing growth response, associated feed cost and survival of grass carp (Ctenopharyngodon idella) fingerlings for sixty days. Sprouted wheatgrass (Triticum aestivum) was prepared for its inexpensively rich nutrients. Four isonitrogenous test diets were formulated and applied as treatments $(\mathrm{T})$ in triplicates $(\mathrm{R})$. In the control $\left(\mathrm{T}_{1}\right)$, basal inclusion rate of fish meal was $30 \%$, of which $10 \%$ was replaced with wheatgrass powder in $\mathrm{T}_{2}$ and in $\mathrm{T}_{3}$ replacement was $20 \%$. In contrast, $30 \%$ of basal fishmeal was replaced in $\mathrm{T}_{4}$. Grass carp fingerlings $(6.38 \pm 0.21 \mathrm{~cm}$ and $2.83 \pm 0.36$ g) were stocked in twelve aquaria $\left(60 \times 40 \times 45 \mathrm{~cm}^{3}\right)$ each containing $75 \mathrm{~L}$ water, at 10 fish per aquarium, fed test diets at $5 \%$ of body weight twice daily. Prominent effect of wheatgrass supplementation was found on food conversion ratio (FCR) and survival rates. The significantly lowest FCR was observed in $\mathrm{T}_{3}(2.13 \pm 0.42)$ followed by $\mathrm{T}_{2}(2.89 \pm 0.99), \mathrm{T}_{1}(3.01 \pm 1.53)$ and $\mathrm{T}_{4}(3.05 \pm 0.94)$. Besides, fish survival rate was significantly improved in $\mathrm{T}_{2}(90 \%), \mathrm{T}_{3}(93.33 \%)$ and $\mathrm{T}_{4}(93.33 \%)$ compared to the lowest survival in $\mathrm{T}_{1}(83.33 \%)$. In conformity, fish tolerance $\left(\mathrm{LT}_{50}\right)$ to low $\mathrm{pH}$ stressor was also increased with wheatgrass supplementation. The other growth parameters among the treatments were statistically similar with highest specific growth rate and fish production in $\mathrm{T}_{3}(1.13 \pm 0.12 \% /$ day and $2.28 \pm 0.13$ tons/ha). Dietary wheatgrass did not affect the fish carcass composition rather gave better result to some extents. The significantly highest carcass protein and lowest moisture was retained in $\mathrm{T}_{3}(14.13 \pm 0.05 \%$ and $74.91 \pm 0.25 \%$ respectively), whereas comparatively higher lipid and mineral (ash) content was found in $\mathrm{T}_{1}(7.69 \pm 0.02 \%$ and $2.35 \pm 0.27 \%$ respectively). Importantly, feed formulation cost was reduced by $2.61,4.89$, and $7.71 \%$ in $\mathrm{T}_{2}, \mathrm{~T}_{3}$, and $\mathrm{T}_{4}$ respectively compared to $\mathrm{T}_{1}$. Therefore, wheatgrass could be promising in juvenile grass carp diet.
\end{abstract}

Keywords: wheatgrass; grass carp; alternate feed source

\section{Introduction}

Searching alternative protein sources from non conventional feedstuff to sustain the aqua-feed industry has become a vital trend of research in the aquaculture world. The current reliance on fishmeal or fish oil for feeding cultured fish has already caused an enormous loss to the wild fisheries resources (Tacon and Metian, 2008; FAO, 2012). Besides, the increased demand, limited supply at soaring price as well as greater propensity of fish meal to pollute the environment have made it urgent to replace with less expensive protein sources to improve the sustainability of aquaculture (Martinez-Llorens et al., 2009). In order to satisfy the quest for finding competitive replacement of fish meal, scientists have switched over a number of dietary ingredients of both animal and plant origin (Booth and Sheppard, 1984; Goda et al., 2007; Audu et al., 2010). However, in most of the cases high cost of animal sources or antinutritional factors of some plant origin had limited their wider use in aqua-feed (Davis, 2015). Although, plant based fish diets always had financial advancement to offer at comparatively lower price because of their availability (Azeredo et al., 2017; Francis et al., 2001). Therefore, in 
this experiment wheatgrass (freshly sprouted first leaves of the common wheat plant, Triticum aestivum) has been investigated as a substitute (plant origin) of fish meal in the diet of grass carp fingerlings to assess its impact on somatic growth and feed cost. Young sprouted wheatgrass are very rich in dietary fiber, antioxidants, minerals (potassium, iron, zinc, calcium, magnesium, copper, manganese and selenium) and vitamins (A, C, E, K, B1, B6, B12 and pantothenic acid) (Meyerowitz, 1992; Murphy, 2002; Shirude, 2011). It also contains a good proportion of basic nutrients viz., lipid, protein and carbohydrates (Devi et al., 2015). Wheatgrass is well known as "power house of nutrients", fifteen pounds of which is nutritionally equal to 350 pounds of ordinary garden vegetables (Mujoriya and Bodla, 2011; Devi et al., 2015). In spite of having huge prospects (locally available, low cost, nutrient rich), use of wheatgrass as dietary ingredient in fish feed is still under progress. However, Nath et al., 2014; and Islam et al., 2017; experimented wheatgrass powder in catfish diets with some promising findings. However, data on carp fish fed wheatgrass based diet is not well in hand yet. Therefore, the present experiment was designed to evaluate the effect of dietary wheatgrass powder substitution with fish meal on juvenile grass carp (Ctenopharyngodon idella).

\section{Materials and Methods}

\subsection{Experimental set-up}

The "BAUAquaponics Oasis" laboratory of the Department of Aquaculture, Bangladesh Agricultural University, was devoted to conduct the experiment for 60 days from $6^{\text {th }}$ June to $6^{\text {th }}$ August 2018 . The feed based experiment, contained of four treatments each with three replications, was run in twelve glass aquaria of 100 liters (size: $60 \times 40 \times 45 \mathrm{~cm}^{3}$ ), containing $75 \mathrm{~L}$ of deep tube well water each. Twelve outlets (with one air stone) from two air pumps (RESUN, Model ACO-003 and 35 watt) were used for continuous aeration in the aquaria. The aquaria were labeled individually as $T_{1} R_{1}, T_{1} R_{2}, T_{1} R_{3}, T_{2} R_{1}, T_{2} R_{2}, T_{2} R_{3}, T_{3} R_{1}, T_{3} R_{2}, T_{3} R_{3}, T_{4} R_{1}, T_{4} R_{2}, T_{4} R_{3}$ and placed following complete randomized block design for scientific justification. Each aquarium was roofed with net frame to prevent jumping out of fish or predatory attack.

\subsection{Stocking of Fish}

The fry of grass carp (initial size: $6.38 \pm 0.21 \mathrm{~cm}$ and $2.83 \pm 0.36 \mathrm{~g}$ ) was collected from local fish hatchery and stocked at a rate of 10 fish per aquarium. During fry transportation oxygenated plastic bags were used to avoid stress and injury. Thereafter the experimental fish were subjected to conditioning into glass aquaria at room temperature ranging $25-30^{\circ} \mathrm{C}$ for a period of 8-10 days at the beginning of the experiment. Throughout the conditioning period, fish were fed control diet twice daily (10:00 am and 4:00 pm) at approximately $3 \%$ of live body weight/day.

\subsection{Wheatgrass powder preparation}

Firstly, 3 clean plastic buckets were taken containing $1 \mathrm{~kg}$ of locally collected wheat seeds each for sprouting. Then the collected wheat seeds were washed and soaked in water for overnight. In the following morning the soaked seeds were sieved, wrapped with cotton cloth and kept in a perforated bucket covered with cloths for 24 hours. Subsequently, the germinated wheat seeds were spread over each $\left(60 \times 30 \times 8 \mathrm{~cm}^{3}\right)$ of nine previously prepared (washed and sun dried) sprouting beds (trays). Water was then sprayed over the trays and covered it for 2 days. Thereafter the sprouted young yellowish wheatgrass were uncovered and brought to sunlight. Harvesting was done, when the seedlings became 6-7 inch long with dark green colors within 8 days, with the cut off stems and weighed. Prior to harvest, water was continued to spray over the sprouting bed twice daily (morning and evening).

After harvesting, blanching was done where the green wheatgrass stems were boiled (over $100{ }^{\circ} \mathrm{C}$ ) for 7 minutes and immediately cooled down in a big bowl by adding ice and one pinch of sea salt $(\mathrm{NaCl})$. As a thumb rule, blanching is done by boiling objects at 75 to $105^{\circ} \mathrm{C}$ temperature for 1 to 10 minutes, in order to retard enzymatic activity, removing gases, setting color, improving texture, stopping the changes of flavor and leaching of water soluble sugars.

The blanched wheatgrass (Figure 1) were kept aerated in room temperature and then dried into a dryer to give it a crunchy texture. These were then crumbled with scissor and finally blended to produce fine powder to be used as fish feed ingredients (Figure 1).

\subsection{Ingredients selection and fish feed formulation}

The feeding trial was supported with four different experimental diets that were formulated form the following ingredients based on their availability, nutrient profiles and market price (Table 1). 
The test diets were formulated with a view to reducing $(0,10,20$, and 30\%) dietary inclusion of fish meal (basal inclusion of $30 \%$ in control $\mathrm{T}_{1}$ ) by adding wheatgrass powder in a progressive manner. Accordingly, the control $\operatorname{diet}\left(\mathrm{T}_{1}\right)$ contained $30 \%$ fishmeal but no wheatgrass powder. Whereas in $\mathrm{T}_{2}, 10 \%$ of fish meal was replaced with wheatgrass powder; hence it contained $27 \%$ fish meal and 3\% wheatgrass powder. In order to represent $20 \%$ replacement, $\mathrm{T}_{3}$ contained $24 \%$ fishmeal and $6 \%$ of wheatgrass powder. In $\mathrm{T}_{4} 30 \%$ of fishmeal was replaced with $9 \%$ inclusion of wheatgrass powder (Table 2).

Pearson square method was followed to calculate the dietary inclusion rate of different ingredients in order to formulate isonitrogenous (around $31 \%)$ test diets. Sinking dry pellet feed $(0.5 \mathrm{~mm}$ diameter) was prepared with extruded feed pellet machine and sun dried. Prepared feed were stored in air tight polythene bags at $4^{\circ} \mathrm{C}$ in refrigerator before feeding the fish. The proximate composition of the test diets was also determined (AOAC, 1990) that has been shown in Table 3. Some precautionary actions were also taken in preparing the ingredients for feed formulation such as measured mustard oil cake was soaked overnight and soybean meal was pre-boiled to minimize their glucocyanate effects.

\subsection{Fish feeding trial, sampling and data analysis}

Throughout the feeding trial, experimental fish were fed (hand feeding) with the respective test diets twice daily (10 am and $5 \mathrm{pm}$ ) at $5 \%$ of their body weight in each aquarium. Siphoning was employed to drain $25 \%$ of the aquarium water daily that ensured removal of uneaten feed and faces. However, same amount of clean water was also added daily to maintain the water level in the aquarium. Besides daily water exchange, each aquarium was completely drained fortnightly (during sampling) to keep environmental homogeneity.

Sampling of fish and water quality parameters were done biweekly. Fish were sampled randomly from individual treatment to observe their average length and weight as well as their response to the test diets by calculating the growth parameters such as length gain $(\mathrm{cm})$, weight gain $(\mathrm{g})$, percent weight gain, specific growth rate (SGR, \%/day), food conversion ratio (FCR), survival rate (\%) and fish production (kg/ha). Fish carcass profile was also determined following the standard procedure of AOAC (1990). Furthermore, water quality parameters such as dissolved oxygen $(\mathrm{mg} / \mathrm{L})$, water temperature $\left({ }^{\circ} \mathrm{C}\right), \mathrm{pH}$, ammonia and nitrite contents were measured using portable DO meter, thermometer, $\mathrm{pH}$ meter and ammonia testing kits respectively.

Moreover, collected data were loaded in the computer and after final harvest, data were subjected to one-way ANOVA for statistical analysis (Snedecor and Cochran, 1994). The least significant difference was used for comparison of the mean values ascertained from different treatments by Duncan's New Multiple Range Test (Duncan, 1955).

\subsection{Low pH stress test}

Tolerance to low $\mathrm{pH}$ stressor $(\mathrm{pH} 3)$ of the experimental fish was also evaluated to determine the impact of dietary wheatgrass incorporation on the fish fitness. Therefore, after the completion of feeding trail, 6 fish from each treatment were randomly selected and transferred to a $20 \mathrm{~L}$ container holding water having $\mathrm{pH} 3$. In order to prepare this low $\mathrm{pH}$ water ( $\mathrm{pH} 3$ ), deep tube-well water was strongly aerated for $24 \mathrm{~h}$ and gradually mixed with nitric acid $\left(\mathrm{HNO}_{3}\right)$. The aquaria for stress test were facilitated with continuous aeration and kept under ambient temperature. Time required attaining $50 \%$ mortality of the test fish was calculated as median lethal time $\left(\mathrm{LT}_{50}\right)$.

\section{Results and Discussion}

\subsection{Production of sprouted wheatgrass}

The total collection of wheatgrass powder from nine sprouting beds (trays) was $500 \mathrm{~g}$. In order to obtain this, each tray $\left(60 \times 30 \times 8 \mathrm{~cm}^{3}\right)$ was initially sprayed with $250 \mathrm{~g}$ of raw wheat seeds. Notably, around $20 \%$ wheatgrass powder was retained from the sprouted live wheatgrass. Therefore, average sprouted wheatgrass production rate was $277.78 \mathrm{~g}$ (live weight) per tray.

\subsection{Somatic response of grass carp to test diets \\ 3.2.1. Growth parameters}

Dietary substitution of any unconventional ingredients always raises the question about its palatability to the target fish. In this experiment, progressive inclusion of wheatgrass powder in the test diets were well accepted by the grass carp fingerlings as they fed steadily but actively and there was almost no feed left over after twenty minutes of feed delivery. Grass carp are herbivorous in nature but also readily accept formulated pellets under culture conditions ( $\mathrm{Ni}$ and Wang, 1999; George, 1982). Therefore, having plant origin might have aided 
wheatgrass contributing to the palatability of the diets. However, wheatgrass powder has also been evaluated in the diet of catfish without hampering diets' acceptability (Nath et al., 2014; Islam et al., 2017).

In case of initial length and weight there was no significant difference $(\mathrm{P}>0.05)$ among the treatments. After 60 days of grass carp nursing, the highest mean length gain $(\mathrm{cm})$ was observed in $T_{3}(1.05 \pm 0.39 \mathrm{~cm})$, followed by $\mathrm{T}_{4}(0.97 \pm 0.28 \mathrm{~cm}), \mathrm{T}_{2}(0.95 \pm 0.29 \mathrm{~cm})$ and $\mathrm{T}_{1}(0.78 \pm 0.81 \mathrm{~cm})$, although the values were statistically similar. In contrast, fish in $\mathrm{T}_{3}$ attained maximum mean weight gain $(\mathrm{g})$ of $2.68 \pm 0.18 \mathrm{~g}$, but the lowest was found in $\mathrm{T}_{4}$ $(2.13 \pm 0.56 \mathrm{~g})$. However, the differences were insignificant $(\mathrm{P}>0.05)$ among the treatments (Table 4). The short rearing period (60 days) and/or some experimental error could be responsible for statistical non-significance.

In a similar fashion, the highest Specific growth rate (SGR, \%/day) and fish production (tons/ha) were experienced in $\mathrm{T}_{3}\left(1.13 \pm 0.12 \% /\right.$ day and $2.28 \pm 0.13$ tons/ha) and the lowest in $\mathrm{T}_{4}(0.95 \pm 0.19 \% / \mathrm{day}$ and $2.04 \pm 0.24$ tons/ha) without any significant difference $(\mathrm{P}>0.05)$. The observed SGR (\%/day) values have outweighed the findings of Islam et al. (2017), who reported SGR values ranged from 0.46 to $0.77 \% /$ day for stinging catfish (Heteropneustes fossilis) and that of Nath et al. (2014), who documented SGR value $0.29 \% /$ day for Asian catfish (Clarias batrachus) in wheatgrass based feeding trials. Species variation and environmental factors might be the reason behind these differences. Again, the fish production in this experiment was continued to increase with the increase of dietary wheatgrass supplementation, till $20 \%$ of fish meal replacement with wheatgrass powder in $\mathrm{T}_{3}$, but dropped when the replacement rose to $30 \%$ in $\mathrm{T}_{4}$. Correspondingly, review of literature has made it known that substitution of fish meal with plant based ingredients up to a certain level in fish diets results in positive response but higher dietary substitution causes a reduction in growth and immune responses (Lin and Luo 2011, Mokrani et al., 2020).

\subsubsection{Survival rate}

Considering the survival rate, fish fed wheatgrass powder based diets showed significantly improved survival compared to control diet $\left(\mathrm{T}_{1}\right)$. Therefore, juveniles in $\mathrm{T}_{3}$ and $\mathrm{T}_{4}$ enjoyed the highest survival rate $(93.33 \%)$ followed by $\mathrm{T}_{2}(90 \%)$ which were statistically different $(\mathrm{P}<0.05)$ to the lowest survival in $\mathrm{T}_{1}(83.33 \%)$ (Table 4$)$. The fabulous nutritional profile of wheatgrass, loaded with quality minerals $(\mathrm{K}, \mathrm{Ca}, \mathrm{Fe}, \mathrm{Mg}, \mathrm{Na}$ and $\mathrm{S}$ ) and vitamins (A, B, C and E) besides the basic nutrients, had presumably contributed to the better survival with increasing supplement in the test diets (Mujoriya and Bodla, 2011; Anwar et al., 2015; Devi et al., 2015).

Therefore, the overall findings re-emphasize that fishmeal substitution with non-conventional sources (animal or plant origin) to a certain level could be feasible in fish diet without limiting growth (Ayoola, 2010; Rana et al., 2015; Sing et al., 2016; Islam et al., 2017; Daniel, 2018; Osho et al., 2019; Rana et al., 2020).

\subsection{Food conversion ratio (FCR) and feed cost}

Food conversion ratio (FCR) is an effective parameter to evaluate a fish feed as it determines the required amount of feed for per unit of somatic growth. In this study, the lowest FCR was $2.13 \pm 0.42$ found in $\mathrm{T}_{3}$ that was significantly lower $(\mathrm{P}<0.05)$ than the highest FCR in $\mathrm{T}_{4}(3.05 \pm 0.94)$. Although, the FCR value of $\mathrm{T}_{2}(2.89 \pm 0.99)$ was statistically similar to other treatments (Table 4). Similarly, Rana et al., 2020; substituted fishmeal with jute leaf powder in the diet of mrigal (Cirrhinus cirrhosus) fingerlings and reported FCR values ranged between 2.81 and 3.30.

Importantly, feed preparation cost was decreased with the increase of dietary wheatgrass powder in the test diets. For instance, the expense in formulating $\mathrm{T}_{1}$ diet was the highest $(49.85 \mathrm{BDT} / \mathrm{Kg})$, which was subsequently reduced by $2.61 \%, 4.89 \%$, and $7.71 \%$ in $\mathrm{T}_{2}(48.55 \mathrm{BDT} / \mathrm{Kg}), \mathrm{T}_{3}(47.41 \mathrm{BDT} / \mathrm{Kg})$ and $\mathrm{T}_{4}(46.01 \mathrm{BDT} / \mathrm{Kg})$ respectively (Figure 2). Thus the experiment signifies that replacement of fish meal with low cost wheatgrass powder in the diet of juvenile grass carp could substantially reduce feed cost and show conformity with the findings of Rana et al., 2020. Moreover, reduction in feed cost, worth more than $60 \%$ of total aquaculture cost (Gadzama and Ndudim, 2019), has brought wheatgrass powder under the shades of light as a promising ingredients in the diet of Indian major carps.

\subsection{Fish carcass composition}

Carcass composition of the tested fish has been shown in Table 5. The findings reveal that, significantly highest carcass protein and lowest moisture was retained in $\mathrm{T}_{3}(14.13 \pm 0.05 \%$ and $74.91 \pm 0.25 \%$ respectively). In contrast, comparatively higher lipid and mineral (ash) content was found in $\mathrm{T}_{1}(7.69 \pm 0.02 \%$ and $2.35 \pm 0.27 \%$ respectively) which were statistically similar with other treatments except the lowest lipid content in $\mathrm{T}_{4}$ $(6.68 \pm 0.27 \%)$. Besides, fiber and carbohydrate profiles did not vary significantly among the treatments. Notably, fiber content was increased with progressive addition of wheatgrass in the test diets. However, the observed protein contents are slightly lower but lipid and mineral (ash) contents are higher than the findings of 
Ashraf et al., 2011; who reported $74.30 \pm 0.07 \%$ moisture, $20.00 \pm 0.15 \%$ protein, $2.52 \pm 0.01 \%$ lipid and $1.4 \pm 0.2 \%$ ash content in grass carp. This variation might be due to the diet and age variation of the fish. To sum up, addition of wheatgrass in place of fishmeal did not affect the quality of fish greatly rather improved consumer digestibility to some extent by increasing carcass fiber. Nandeesha et al., 1995; also concluded that plant based diets had contributed to boost up carcass protein and fat levels in Indian major carps.

\subsection{Water quality parameters}

The water quality parameters (Table 6) of the trial aquaria ranged between, $\mathrm{pH}$ (7.82 and 8.84), dissolved (DO) oxygen $(6.57$ and $7.93 \mathrm{ppm})$, temperature $\left(28\right.$ and $\left.29.5^{\circ} \mathrm{C}\right)$, ammonia $(0.08$ and $0.33 \mathrm{mg} / \mathrm{L})$ and nitrite $(0.07$ and $0.66 \mathrm{mg} / \mathrm{L}$ ) among the treatments throughout the study period. Consequently, the parameters were within the acceptable range for grass carp as well as fish culture (Swingle, 1967; Ni and Wang, 1999). Therefore, it could be summarize that the rearing water was safe for fish wellbeing and had no decisive effect on the response of fish to the test diets.

\subsection{Low $\mathrm{pH}$ stress test}

Adaptation to stressed condition is an important reference of fish robustness. In this experiment, after the feeding trials fish were subjected to low $\mathrm{pH}$ stress test $(\mathrm{pH} 3.0)$. From the literature, it is understood that $\mathrm{pH}$ below 4.0 is lethal to fish, whereas the recommended range is 6.8-9.0 (Swingle, 1967). Results showed that 50\% of the fish in $\mathrm{T}_{1}$ died sooner after 6 minutes $\left(\mathrm{LT}_{50}=6\right.$ minutes) of exposure to low $\mathrm{pH}$ stress than fish in other treatments. In contrast, the values of median lethal time $\left(\mathrm{LT}_{50}\right)$ for the fish in $\mathrm{T}_{2}, \mathrm{~T}_{3}$ and $\mathrm{T}_{4}$ were 10,14 and 16 minutes respectively (Figure 3). These imply that dietary addition of wheatgrass (high mineral content) had improved resilience of the test fish which conforms with the findings of Rana et al., 2020.

Table 1. Basic nutrients and market price of the selected feed ingredients.

\begin{tabular}{|lllll|}
\hline Ingredients & \% Crude protein & \% Crude lipid & \% Carbohydrates & Price (BDT/kg) \\
\hline Fish meal & 56 & 8.5 & 2.7 & 80 \\
\hline Wheatgrass powder & 16.5 & 2 & 60 & 25 \\
\hline Mustard oil cake & 30 & 11 & 35 & 35 \\
\hline Rice bran & 12 & 12 & 55 & 35 \\
\hline Soya bean meal & 40 & 15 & 30 & 42 \\
\hline Wheat bran & 12 & 7.5 & 60 & 20 \\
\hline Wheat flower & 12 & 2.5 & 70 & 25 \\
\hline Soya oil & 0 & 100 & 0 & 80 \\
\hline Minerals and vitamin premix & 0 & 0 & 0 & 100 \\
\hline
\end{tabular}

Table 2. Dietary inclusion rate ( $\mathrm{g}$ ) of different ingredients used in formulating $100 \mathrm{~g}$ of the test diets for grass carp fingerlings.

\begin{tabular}{|lllll|}
\hline $\begin{array}{l}\text { Feed } \\
\text { ingredients }\end{array}$ & $\begin{array}{l}\mathbf{T}_{\mathbf{1}} \\
\mathbf{( 0 \%} \text { replacement of } \\
\text { fish meal with } \\
\text { wheatgrass powder) }\end{array}$ & $\begin{array}{l}\mathbf{T}_{\mathbf{2}} \\
\mathbf{( 1 0 \%} \text { replacement of } \\
\text { fish meal with } \\
\text { wheatgrass powder) }\end{array}$ & $\begin{array}{l}\mathbf{T}_{\mathbf{3}} \\
\mathbf{2 0 \%} \text { replacement of } \\
\text { fish meal with } \\
\text { wheatgrass powder) }\end{array}$ & $\begin{array}{l}\mathbf{T}_{\mathbf{4}} \\
\mathbf{3 0 \%} \text { replacement of } \\
\text { fish meal with } \\
\text { wheatgrass powder) }\end{array}$ \\
\hline Fish meal & 30 & 27 & 24 & 21 \\
\hline Wheatgrass & 0 & 3 & 6 & 9 \\
\hline Mustard oil cake & 20 & 18 & 18 & 17 \\
\hline Rice bran & 20 & 17 & 17 & 12 \\
\hline Soya bean meal & 10 & 15 & 18 & 23 \\
\hline Wheat bran & 10 & 10 & 10 & 3 \\
\hline Wheat flower & 5 & 5 & 2 & 3 \\
\hline Soya oil & 3 & 3 & 3 & 2 \\
\hline $\begin{array}{l}\text { Minerals and } \\
\text { vitamin premix }\end{array}$ & 2 & 2 & 2 & 100 \\
\hline Grand Total & 100 & 100 & 100 & 3 \\
\hline
\end{tabular}


Table 3. Proximate composition (\%) of different test diets.

\begin{tabular}{|lllllll|}
\hline Treatments & Moisture & Crude lipid & Crude protein & Ash & Crude fiber & $\begin{array}{l}\text { Nitrogen Free } \\
\text { Extract (NFE) }\end{array}$ \\
\hline $\mathrm{T}_{1}$ & 12.32 & 6.74 & 31 & 12.54 & 4.34 & 32.31 \\
\hline $\mathrm{T}_{2}$ & 12.92 & 6.54 & 30.86 & 11.83 & 5.14 & 32.18 \\
\hline $\mathrm{T}_{3}$ & 12.13 & 5.53 & 30.51 & 11.60 & 5.79 & 33.69 \\
\hline $\mathrm{T}_{4}$ & 12.03 & 5.78 & 30.58 & 11.37 & 6.03 & 34.11 \\
\hline
\end{tabular}

Table 4. Growth parameters of grass carp fingerlings fed test diets.

\begin{tabular}{|llllllll|}
\hline & $\begin{array}{l}\mathbf{T}_{\mathbf{1}} \\
\mathbf{( 0 \%} \text { replacement } \\
\text { of fish meal with } \\
\text { wheatgrass } \\
\text { powder) }\end{array}$ & $\begin{array}{l}\mathbf{T}_{\mathbf{2}} \\
\text { replacement of } \\
\text { Parameters meal with } \\
\text { wheatgrass } \\
\text { powder) }\end{array}$ & $\begin{array}{l}\mathbf{T}_{\mathbf{3}} \\
\mathbf{( 2 0 \%} \\
\text { replacement of meal with } \\
\text { wheatgrass } \\
\text { powder) }\end{array}$ & $\begin{array}{l}\mathbf{T}_{\mathbf{4}} \\
\mathbf{3 0 \%} \\
\text { replacement of } \\
\text { fish meal with } \\
\text { wheatgrass } \\
\text { powder) }\end{array}$ & F-value p-value & $\begin{array}{l}\text { Level of } \\
\text { Significance }\end{array}$ \\
\hline $\begin{array}{l}\text { Mean initial } \\
\text { length(cm) }\end{array}$ & $6.33( \pm 0.20)^{\mathrm{a}}$ & $6.44( \pm 0.15)^{\mathrm{a}}$ & $6.42( \pm 0.39)^{\mathrm{a}}$ & $6.34( \pm 0.09)^{\mathrm{a}}$ & 0.15 & 0.93 & $\mathrm{NS}$ \\
\hline $\begin{array}{l}\text { Mean final } \\
\text { length(cm) }\end{array}$ & $7.11( \pm 0.96)^{\mathrm{a}}$ & $7.38( \pm 0.36)^{\mathrm{a}}$ & $7.48( \pm 0.25)^{\mathrm{a}}$ & $7.32( \pm 0.48)^{\mathrm{a}}$ & 0.25 & 0.86 & $\mathrm{NS}$ \\
\hline $\begin{array}{l}\text { Mean length } \\
\text { gain }\end{array}$ & $0.78( \pm 0.81)^{\mathrm{a}}$ & $0.95( \pm 0.29)^{\mathrm{a}}$ & $1.05( \pm 0.39)^{\mathrm{a}}$ & $0.97( \pm 0.28)^{\mathrm{a}}$ & 0.16 & 0.92 & $\mathrm{NS}$ \\
\hline $\begin{array}{l}\text { Mean initial } \\
\text { weight(g) }\end{array}$ & $2.88( \pm 0.46)^{\mathrm{a}}$ & $2.89( \pm 0.12)^{\mathrm{a}}$ & $2.78( \pm 0.29)^{\mathrm{a}}$ & $2.76( \pm 0.58)^{\mathrm{a}}$ & 0.15 & 0.91 & $\mathrm{NS}$ \\
\hline $\begin{array}{l}\text { Mean final } \\
\text { weight }\end{array}$ & $5.18( \pm 0.14)^{\mathrm{a}}$ & $5.24( \pm 0.75)^{\mathrm{a}}$ & $5.47( \pm 0.31)^{\mathrm{a}}$ & $4.89( \pm 0.57)^{\mathrm{a}}$ & 0.68 & 0.59 & $\mathrm{NS}$ \\
\hline $\begin{array}{l}\text { Mean weight } \\
\text { gain }\end{array}$ & $2.30( \pm 0.58)^{\mathrm{a}}$ & $2.35( \pm 0.72)^{\mathrm{a}}$ & $2.68( \pm 0.18)^{\mathrm{a}}$ & $2.13( \pm 0.56)^{\mathrm{a}}$ & 0.54 & 0.67 & $\mathrm{NS}$ \\
\hline $\begin{array}{l}\text { Percent } \\
\text { weight gain }\end{array}$ & $83.41( \pm 35.24)^{\mathrm{a}}$ & $81.35( \pm 24.5)^{\mathrm{a}}$ & $97.21( \pm 14.4)^{\mathrm{a}}$ & $77.27( \pm 20.58)^{\mathrm{a}}$ & 0.36 & 0.78 & $\mathrm{NS}$ \\
\hline FCR & $3.01( \pm 1.53)^{\mathrm{a}}$ & $2.89( \pm 0.99)^{\mathrm{ab}}$ & $2.13( \pm 0.42)^{\mathrm{b}}$ & $3.05( \pm 0.94)^{\mathrm{a}}$ & 2.85 & 0.049 & $*$ \\
\hline $\begin{array}{l}\text { SGR } \\
(\% / d a y)\end{array}$ & $0.99( \pm 0.31)^{\mathrm{a}}$ & $0.98( \pm 0.22)^{\mathrm{a}}$ & $1.13( \pm 0.12)^{\mathrm{a}}$ & $0.95( \pm 0.19)^{\mathrm{a}}$ & 0.39 & 0.76 & $\mathrm{NS}$ \\
\hline $\begin{array}{l}\text { Survival rate } \\
(\%)\end{array}$ & $83.33^{\mathrm{b}}$ & $90.00^{\mathrm{a}}$ & $93.33^{\mathrm{a}}$ & $93.33^{\mathrm{a}}$ & 3.83 & 0.042 & $*$ \\
\hline $\begin{array}{l}\text { Fish } \\
\text { production } \\
\text { (tons/ha) }\end{array}$ & $2.16( \pm 0.06)^{\mathrm{a}}$ & $2.19( \pm 0.31)^{\mathrm{a}}$ & $2.28( \pm 0.13)^{\mathrm{a}}$ & $2.04( \pm 0.24)^{\mathrm{a}}$ & 0.682 & 0.59 & $\mathrm{NS}$ \\
\hline
\end{tabular}

Note: Values are mean \pm Standard deviation from triplicate groups. Values in a row having similar letters (s) or without letters do not differ significantly whereas values bearing the dissimilar letter (s) differ significantly as per DMRT (Duncan's New Multiple Range Test). * significant at $\mathrm{P} \leq 0.05$; ** significant at $\mathrm{P} \leq 0.01$; NS non-significant at $\mathrm{P}>0.05$

Table 5. Carcass composition (\%) of experimental grass carp (wet weight basis) fingerlings.

\begin{tabular}{|c|c|c|c|c|c|c|c|}
\hline Parameters & $\begin{array}{l}\mathbf{T}_{1} \\
(0 \% \\
\text { replacement of } \\
\text { fish meal with } \\
\text { wheatgrass } \\
\text { powder) }\end{array}$ & $\begin{array}{l}T_{2} \\
(10 \% \\
\text { replacement of } \\
\text { fish meal with } \\
\text { wheatgrass } \\
\text { powder) }\end{array}$ & $\begin{array}{l}\mathbf{T}_{3} \\
(20 \% \\
\text { replacement of } \\
\text { fish meal with } \\
\text { wheatgrass } \\
\text { powder) }\end{array}$ & $\begin{array}{l}\mathbf{T}_{4} \\
(30 \% \\
\text { replacement of } \\
\text { fish meal with } \\
\text { wheatgrass } \\
\text { powder) }\end{array}$ & F-value & p-value & $\begin{array}{l}\text { Level of } \\
\text { Significance }\end{array}$ \\
\hline Moisture & $75.32( \pm 0.12)^{\mathrm{bc}}$ & $75.67( \pm 0.59)^{\mathrm{ab}}$ & $74.91( \pm 0.25)^{\mathrm{bc}}$ & $76.04( \pm 0.09)^{\mathrm{a}}$ & 6.52 & 0.02 & $*$ \\
\hline Crude lipid & $7.69( \pm 0.02)^{\mathrm{a}}$ & $7.59( \pm 0.41)^{\mathrm{a}}$ & $7.41( \pm 0.23)^{\mathrm{a}}$ & $6.68( \pm 0.27)^{b}$ & 8.65 & 0.007 & $* *$ \\
\hline Crude protein & $13.73( \pm 0.15)^{b}$ & $13.45( \pm 0.25)^{b}$ & $14.13( \pm 0.05)^{\mathrm{a}}$ & $13.47( \pm 0.13)^{b}$ & 11.88 & 0.003 & $* *$ \\
\hline Ash & $2.35( \pm 0.27)^{\mathrm{a}}$ & $2.20( \pm 0.07)^{\mathrm{a}}$ & $2.32( \pm 0.09)^{\mathrm{a}}$ & $2.33( \pm 0.11)^{\mathrm{a}}$ & 0.56 & .66 & NS \\
\hline Fiber & $0.48( \pm 0.31)^{\mathrm{a}}$ & $0.47( \pm 0.18)^{\mathrm{a}}$ & $0.62( \pm 0.13)^{\mathrm{a}}$ & $0.61( \pm 0.03)^{\mathrm{a}}$ & 0.53 & 0.68 & NS \\
\hline Carbohydrate & $0.42( \pm 0.10)^{b}$ & $0.59( \pm 0.22)^{\mathrm{ab}}$ & $0.60( \pm 0.29)^{\mathrm{ab}}$ & $0.88( \pm 0.08)^{\mathrm{a}}$ & 2.95 & 0.09 & NS \\
\hline
\end{tabular}

Note: Values are mean \pm Standard deviation from triplicate groups. Values in a row having similar letters (s) or without letters do not differ significantly whereas values bearing the dissimilar letter (s) differ significantly as per DMRT (Duncan's New Multiple Range Test). * significant at $\mathrm{P} \leq 0.05$; ** significant at $\mathrm{P} \leq 0.01$; NS non-significant at $\mathrm{P}>0.05$ 
Table 6. The water quality parameters over the feeding trial.

\begin{tabular}{|lllll|}
\hline Parameters & $\begin{array}{l}\mathbf{T}_{\mathbf{1}} \\
\mathbf{( 0 \%} \text { replacement of } \\
\text { fish meal with } \\
\text { wheatgrass powder })\end{array}$ & $\begin{array}{l}\mathbf{T}_{\mathbf{2}} \\
\mathbf{( 1 0 \%} \text { replacement } \\
\text { of fish meal with } \\
\text { wheatgrass powder })\end{array}$ & $\begin{array}{l}\mathbf{T}_{\mathbf{3}} \\
\mathbf{( 2 0 \%} \text { of } \\
\text { of fish meacement with } \\
\text { wheatgrass powder) }\end{array}$ & $\begin{array}{l}\mathbf{T}_{\mathbf{4}} \\
\text { (30\% replacement } \\
\text { of fish meal with } \\
\text { wheatgrass powder) }\end{array}$ \\
\hline $\mathrm{pH}$ & $8.4 \pm 0.44$ & $8.2 \pm 0.1$ & $8.33 \pm 0.32$ & $8.03 \pm 0.21$ \\
\hline $\mathrm{DO}(\mathrm{ppm})$ & $7.87 \pm 0.06$ & $7.73 \pm 0.12$ & $7.33 \pm 0.76$ & $7.63 \pm 0.38$ \\
\hline Temperature $\left({ }^{\circ} \mathrm{C}\right)$ & $28.57 \pm 0.40$ & $28.6 \pm 0.17$ & $29 \pm 0.5$ & $28.4 \pm 0.40$ \\
\hline Ammonia(mg/L) & $0.14 \pm 0.06$ & $0.22 \pm 0.11$ & $0.14 \pm 0.05$ & $0.15 \pm 0.08$ \\
\hline Nitrite $(\mathrm{mg} / \mathrm{L})$ & $0.36 \pm 0.30$ & $0.29 \pm 0.18$ & $0.07 \pm 0.00$ & $0.13 \pm 0.04$ \\
\hline
\end{tabular}

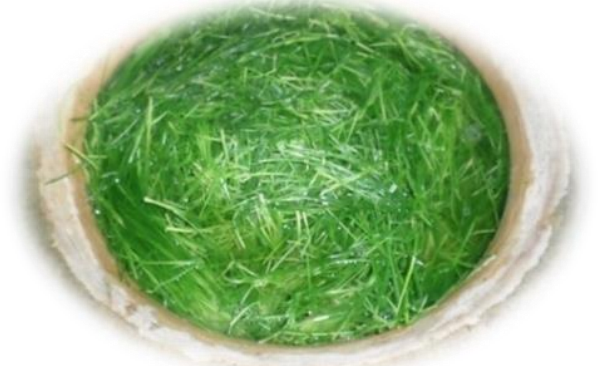

A. Blanched wheatgrass stem

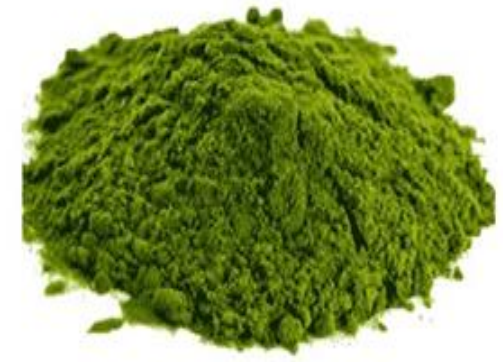

B. Wheatgrass powder

Figure 1. Preparation of wheatgrass powder.

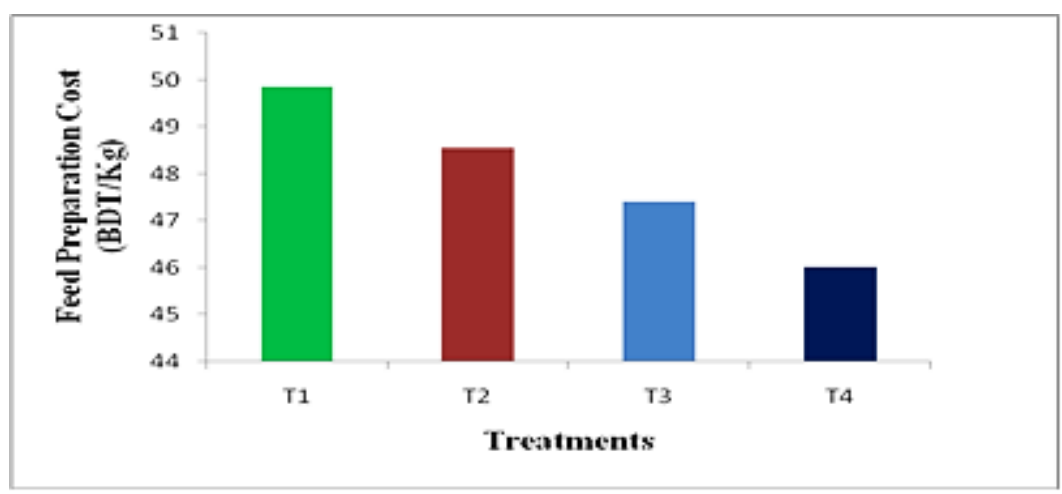

Figure 2. Feed formulation cost in different treatments. (BDT/Kg)

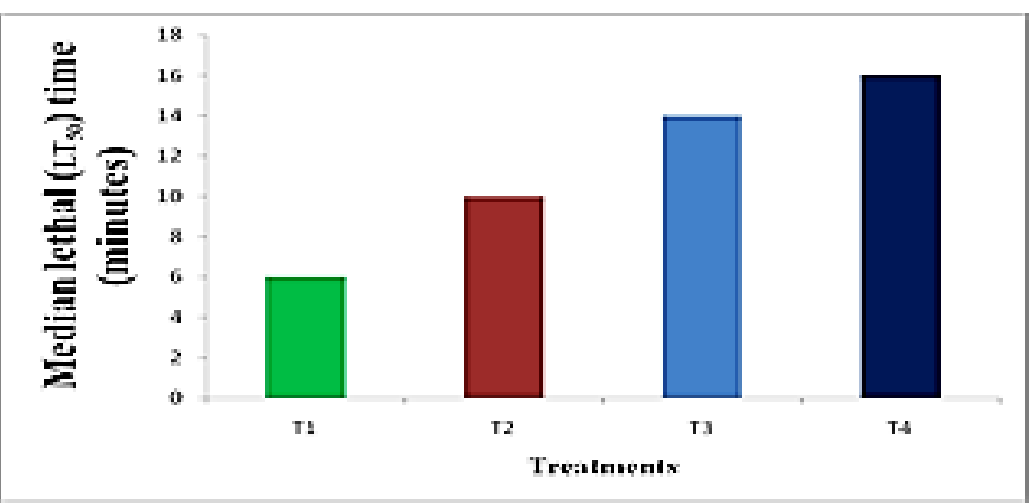

Figure 3. Response of fish to low pH stress test.

\section{Conclusions}

The overall somatic performance of grass carp (C. idella) fed wheatgrass supplemented test diets was satisfactory compared to control diet (no dietary wheatgrass inclusion). Notably, fish survival was substantially improved. The FCR value and feed formulation cost of the respective diets were reduced in a good amount. 
However, the sensitivity to wheatgrass (plant feedstuffs) based diets is species specific and demand extensive research to certify it as a fish feed ingredient in a broad context.

\section{Conflict of interest}

None to declare.

\section{References}

Anwar DA, AA El-Yazied, TF Mohammadi and MMF Abdallah, 2015. Wheatgrass Juice and its nutritional value as affected by sprouting condition. Arab Univ. J. Agril. Sci., 23: 37-49.

AOAC. 1990. Official methods of analysis. 15th edn. Association of Official Analytical Chemists, Washington, D.C., USA.

Ashraf M, A Zafar, A Rauf, S Mehboob and NA Qureshi, 2011. Nutritional values of wild and cultivated silver carp (Hypophthalmichthys molitrix) and grass carp (Ctenopharyngodon idella). Int. J. Agric. Biol., 13: 210-214.

Audu BS, KM Adamu and SA Binga, 2010. The effect of substituting fishmeal diets with varying quantities of ensiled parboiled beniseed (Sesamum indicum) and raw african locust bean (Parkia biglobosa) on the growth responses and food utilization of the nile tilapia Oreochromis niloticus. Int. J. Zool. Res., 6: 334-339.

Ayoola AA, 2010. Replacement of fish meal with alternative protein source in aquaculture diets. M.Sc. Thesis, Graduate Faculty of North Carolina State University, U.S.A. pp. 1-120.

Azeredo R, M Machado, E Kreuz, S Wuertz, A Oliva-Teles, P Enes and B Costas, 2017. The european seabass (Dicentrarchus labrax) innate immunity and gut health are modulated by dietary plant-protein inclusion and prebiotic supplementation. Fish Shellfish Immunol., 60: 78-87.

Booth DC and DC Sheppard, 1984. Oviposition of the black soldier fly Hermetia illucens diptera stratiomyidae egg masses timing and site characteristics. Env. Entom., 13: 421-423.

Daniel N, 2018. A review on replacing fish meal in aqua feeds using plant protein sources. Int. J. Fish. Aquat. Stud., 6: 164-179.

Davis DA, 2015. Feed and feeding practices in aquaculture. Woodhead Publishing, Cambridge, Britain.

Devi SK, K Hariprasath, GR Nalini, P Veenaeesh and S Ravichandra, 2015. Wheat grass juice - Triticum aestivum Linn' a therapeutic tool in pharmaceutical research, an overview. Ijppr. Human., 3: 112-121.

Duncan DB, 1955. Multiple range and multiple F tests. Biometrics, 11: 1-42.

FAO. 2012. Fisheries statistics. Food and Agricultural Organization of the United Nations (FAO), Rome, Italy.

Francis G, HPS Makkar and K Becker, 2001. Antinutritional factors present in plant-derived alternate fish feed ingredients and their effects in fish. Aquaculture, 199: 197-227.

Gadzama and Ndudim. 2019. Nutritional composition of housefly larvae meal: a sustainable protein source for animal production - a review. Acta. Sci. Agri., 3: 74-77.

George TT, 1982. The chinese grass carp, Ctenopharyngodon idella, its biology, introduction, control of aquatic macrophytes and breeding in the Suda. Aquaculture, 27: 317-327.

Goda AM, ER El-Haroun and MAK Chowdhury, 2007. Effect of totally or partially replacing fish meal by alternative protein sources on growth of African catfish Clarias gariepinus (Burchell, 1822) reared in concrete tanks. Aquac. Res., 38: 279-287.

Islam T, KMS Rana and MA Salam, 2017. Potential of wheatgrass powder based feed for stinging catfish fry nursing in laboratory condition. Int. J. Fish. Aquat. Stud., 5: 179-184.

Lin S and L Luo, 2011. Effects of different levels of soybean meal inclusion inreplacement for fish meal on growth, digestive enzymes and transaminaseactivities in practical diets for juvenile tilapia, Oreochromis niloticus $\times$ O. aureus. Anim. Feed Sci. Technol. 168: 80-87.

Martínez-Llorens, Silvia, AT Vidal, IJ Garcia, MP Torres and MJ CerdÁ. 2009. Optimum dietary soybean meal level for maximizing growth and nutrient utilization of on-growing gilthead sea bream (Sparus Aurata). Aquac. Nutr., 15: 320-28.

Meyerowitz S, 1992. "Nutrition in grass"-wheatgrass nature's finest medicine: the complete guide to using grass foods \& juices to revitalize your health. 6th ed. Great Barrington (Massachusetts): Sproutman publications, USA. pp. 1-53.

Mokrani A, M Ren, H Liang, Q Yang, K Ji, HC Kasiya and X Ge, 2020. Effect of the total replacement of fishmeal with plant proteins and supplemental essential amino acids in the extruded diet on antioxidants genes, enzyme activities, and immune response in juvenile blunt snout bream. Aquacult. Int., 28: 555-568.

Mujoriya R and DRB Bodla, 2011. A study on wheat grass and its nutritional value. Food Sci. Qual. Mngmt., 2: 1-8. 
Murphy S, 2002. Wheatgrass, healthy for the body and the bank account. ABC Landline. Archived from the original on 2 December 2002. Retrieved 6 October 2006.

Nandeesha MC, SS De Silva and D Krishna, 1995. Use of mixed feeding schedules in fish culture: performance of common carp, Cyprinus carpio L. on plant and animal based diets. Aquac. Res., 26: 161-166.

Nath DT, S Hashem, and MA Salam, 2014. Asian catfish fry (Clarias batrachus) rearing with wheatgrass powder mixed formulated feed in plastic half drum. Int. J. Fish. Aquat. Stud., 1: 162-168.

Ni D and J Wang, 1999. Biology and diseases of grass carp. Ed. Ni D and J Wang, Science Press, Beijing, China.

Osho FE, EK Ajani, O Orisasona, and T Obafemi, 2019. Replacement of fishmeal with clariid fish offal in the diet of african catfish, Clarias gariepinus (Burchell, 1822) juveniles. Nig. J. Fish. Aqua., 7: 40 - 48.

Rana KMS, MA Salam, S Hashem and MA Islam, 2015. Development of black soldier fly larvae production technique as an alternate fish feed. Int. J. Res. Fish. Aqua., 5: 41-47.

Rana KMS, P Biswas, and MA Salam, 2020. Evaluation of jute leaf as substitute of fish meal in the diet of mrigal (Cirrhinus cirrhosus) fingerlings. Int. J. Agril. Res. Innov. Tech., 10: 117-122.

Shirude AA, 2011. Phytochemical and pharmacological screening of wheatgrass ( Triticum Aestivum L). Int. J. Pharma. Sci. Rev. Res., 9: 159-164.

Singh P, BN Paul, GC Rana, and SS Giri, 2016. Evaluation of jute leaf as feed ingredient for Labeo rohita fingerlings. Indian J. Anim. Nutr., 33: 203-207.

Snedecor GW and WG Cochran, 1994. Statistical methods. Oxford and IBH Publishing Company, Calcutta, West Bengal, India.

Swingle HS, 1967. Standardizations of chemical analyses for water and pond muds. FAO Fish Rep., 4: 397-421.

Tacon AGJ and M Metian, 2008. Global overview on the use of fish meal and fish oil in industrially compounded aquafeed: trends and future prospects. Aquaculture, 285: 148-158. 